\title{
A Rare Case with Co-Occurrence of Thyroid Papillary Microcarcinoma and Multifocal Renal Cell Carcinoma Metastasis to Thyroid Gland
}

\begin{abstract}
Ahmet Kucukarda1, Mehmet Celik ${ }^{2}$, Burak Andac', Nuray Can ${ }^{3}$, Ebru Tastekin ${ }^{3}$, Atakan Sezer ${ }^{4}$, Semra Ayturk ${ }^{2}$, Sibel Guldiken ${ }^{2}$, Armagan Tugrul ${ }^{2}$
\end{abstract}

\section{Abstract}

Renal cell carcinoma is a common malignancy of uroepithelial region. It may metastasize even years after nephrectomy. Metastatic disease of thyroid gland is rare, the most common one is being renal cell carcinoma. Unlike the cases reported in the literature as tumor to tumor metastasis, our case had co-occurrence of multifocal renal cell carcinoma metastasis in the left thyroid lobe and thyroid papillary carcinoma in the right thyroid lobe, which were diagnosed at the same time. We presented this case due to its rare occurrence.

\section{Keywords}

Thyroid Carcinoma; Renal Cell Carcinoma; Neoplasm Metastasis.

\section{Introduction}

Metastatic diseases of thyroid gland are rarely seen. Metastatic tumors constitute $2-3 \%$ of all thyroid malignancies. This incidence has been reported to be higher as $5-24 \%$ in autopsy series [1]. Thyroid metastasis of various type solid tumors such as malignant melanoma, renal cell carcinoma, breast cancer, lung cancer, head and neck tumors and hematological malignancies have been reported [2]. Although thyroid metastasis of renal cell carcinoma (RCC) has been reported, cases with co-occurrence of primary thyroid cancer and thyroid metastasis of RCC have mostly been reported as tumor to tumor metastasis in the literature [1]. Our case differently had concurrent thyroid metastasis of multifocal RCC and papillary thyroid carcinoma (PTC] and was presented due to its rare occurrence.
1 Department of Internal Medicine, Trakya Medical School, University of Trakya, Edirne, Turkey.

2 Department of Internal Medicine, Division of Endocrinology and Metabolism, Trakya Medical School, University of Trakya, Edirne,Turkey.

3 Department of Pathology, Trakya Medical School, University of Trakya, Edirne, Turkey.

4 Department of General Surgery, Trakya Medical School, University of Trakya, Edirne, Turkey.

Contact information:

Ahmet Kucukarda.

Address: Research assistant of Department of Internal Medicine, Trakya University Medical Faculty Edirne, 22030, Turkey.

Tel: +90 28423576 41. Extension: 1117 . Fax: +902842352730 


\section{Case Report}

A 65-year old male patient who had been diagnosed with RCC 2 years ago was referred to our clinic after detection of microcalcific and hypoechoic multiple nodules with hypoechoic halo in the right thyroid lobe on thyroid ultrasonography, the biggest one was being $35 \times 22 \mathrm{~mm}$ in size. The patient had no symptoms and was euthyroid on admission. Anti-TPO and anti-TG were detected to be negative. Pathological examination of fine needle aspiration biopsy specimen obtained from the big nodule in the right lobe revealed oncocytic cell neoplasm and the patient underwent total thyroidectomy. Pathological examination demonstrated clear cell RCC metastasis in 3 focuses $(2.5,1.5$ and $1.2 \mathrm{~cm}$ in size) in the right lobe and in one focus ( $5 \mathrm{~cm}$ in size) in the left lobe. In addition, there were two focuses $(0.6$ and $0.4 \mathrm{~cm}$ in size) of follicular and classical variant papillary microcarcinoma in the right lobe, which had no lymphovascular invasion and extra-thyroidal spread (Figure 1) The patient was scheduled for follow-up with TSH suppression. Neck ultrasonography performed in post-operative 3rd month visit revealed a 16×10 $\mathrm{mm}$ sized, microcalcific and spherical lymph node with no visible fatty hilum in the left cervical chain. Thyroglobulin (TG) level was measured as $0.75 \mathrm{ng} /$ $\mathrm{ml}$ and anti-TG was found to be negative. FNAB and TG wash-out were performed on the lymph

Figure 1: Encapsulated tumor in thyroid gland. Tumor is composed of epithelial cells with clear cytoplasms and small nucleoli showing alveolar pattern (1a: H\&E x40). Tumoral infiltration which has no capsule but similar structure and cytological features (1b: H\&E x100). Tumoral growth in another area with classical papillary thyroid carcinoma features (1c: H\&E x100). Thyroglobulin and TTF-1 immune reaction in adjacent tissues. Note that clear cell tumor shows no staining (1d: Immunoperoxidase, Thyroglobulin x100, 1e: Immunoperoxidase, TTF-1 x100). CD10 immune reaction in clear cell tumor, note the absence of staining in adjacent thyroid tissue (1f: Immunoperoxidase, CD10 x200).
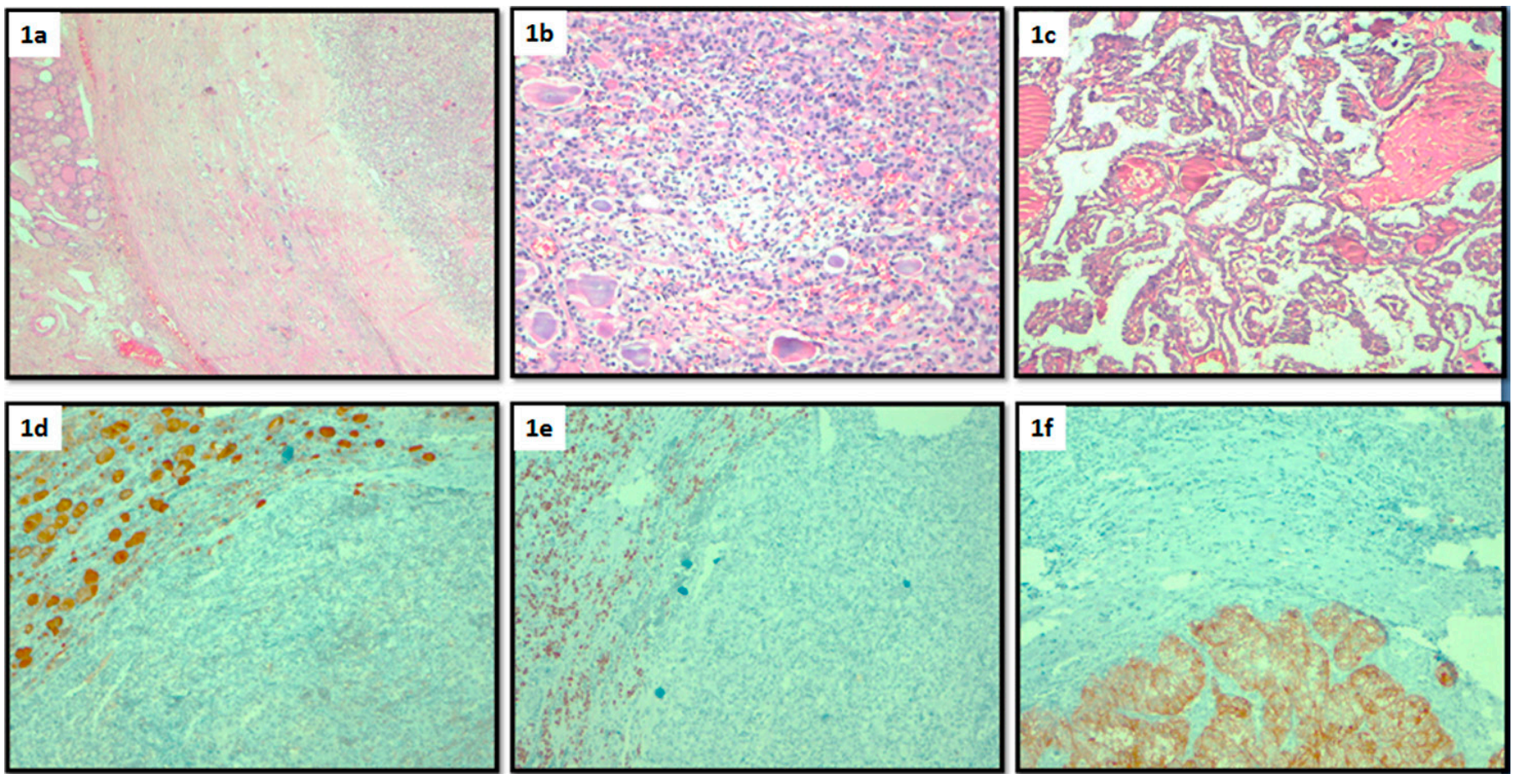
node. Atypical lymphoid cells were detected in biopsy sample and TG wash-out result of the lymph node was $300 \mathrm{ng} / \mathrm{ml}$. The patient underwent modified radical neck dissection. Among 36 lymph nodes extirpated, one was detected to show PTC metastasis. The patient was scheduled for postoperative radioactive iodine treatment.

\section{Discussion}

In clinical series, kidney, lung and skin [melanoma] cancers have been reported to be the most common tumors metastasizing to thyroid gland, while autopsy series reported breast, lung and skin [melanoma] originated tumors more commonly [2-4]. In the literature, renal cell carcinoma was reported as the malignancy which most commonly (48.1\%) metastasizes to thyroid [5]. Renal cell carcinoma is one of the most common cancers of urinary system, which is more common in men and in 6th and $7^{\text {th }}$ decades of life. The most common sites for RCC metastasis are lungs, bone, lymph nodes, liver, adrenal gland and brain, in order of decreasing frequency. Unlike other tumors, it may metastasize even years after nephrectomy [6]. FNAB is useful in the diagnosis of metastatic thyroid masses. Renal cell carcinoma metastasis, nodular hyperplasia and clear cell follicular adenomas appear very similar. Immunohistochemical staining is important in definitive differential diagnosis. CD10, vimentin, keratin and EMA [epithelial membrane antigen] immunoreactivity is especially detected in renal cell carcinoma metastases $[2,7]$. Some renal tumors may cause false negative FDG-PET/CT results due to low glucose metabolism, small tumor size and intratumoral necrosis [8]. Our case also had negative PET/CT result but metastatic RCC. Some studies suggest that metastatic disease was more common in the patients with nodular goiter, adenoma, well-differentiated thyroid carcinoma and thyroiditis when compared to the individuals with normal thyroid tissue, which was thought to be due to abnormal blood supply causing decreased oxygen and iodine content [9].

As a result, immunohistochemical staining is important in the differential diagnosis of histological clear cell changes in the patients with the history of extra-thyroidal malignancy and it should not be overlooked that microenvironment of thyroid nodules provides an attractive media especially for renal cell carcinoma.

\section{Competing interests}

The authors declare no conflicts of interest. All research was conducted with their own resources.

\section{Financial resources}

The authors state that they used their own resources and did not receive financial aid from any institution. 


\section{References}

1. Bohn OL, De las Casas LE, Leon ME. Tumor-to-tumor metastasis: Renal cell carcinoma metastatic to papillary carcinoma of thyroid-report of a case and review of the literature. Head Neck Pathol. 2009; 3(4): 327-30

2. Heffess CS, Wenig BM, Thompson LD. Metastatic renal cell carcinoma to the thyroid gland: a clinicopathologic study of 36 cases. Cancer. 2002; 95(9): 1869-78

3. Dionigi G, Uccella S, Gandolfo M, Lai A, Bertocchi V, Rovera $F$, et al. Solitary intrathyroidal metastasis of renal clear cell carcinoma in a toxic substernal multinodular goiter. Thyroid Res. 2008; 1(1): 6.

4. Sindoni A, Rizzo M, Tuccari G, leni A, Barresi V, Calbo L, et al. Thyroid metastases from renal cell carcinoma: review of the literature. ScientificWorldJournal. 2010; 10: 590-602.

5. Chung AY, Tran TB, Brumund KT, Weisman RA, Bouvet M. Metastases to the thyroid: a review of the literature from the last decade. Thyroid. 2012; 22(3): 258-68.

6. Clara SH, Bruce MW, Lester DT. Metastatic Renal Cell Carcinoma to the Thyroid Gland: a clinicopathologic study of 36 cases. Cancer. 2002; 95: 1869-75.

7. Geramizadeh B, Ravanshad M, Rahsaz M. Useful markers for differential diagnosis of oncocytoma, chromophobe renal cell carcinoma and conventional renal cell carcinoma. Indian J Pathol Microbiol. 2008; 51(2): 167-71.

8. Middendorp M, Maute L, Sauter B, Vogl TJ, Grünwald F. Initial experience with $18 \mathrm{~F}$-fluoroethylcholine PET/CT in staging and monitoring therapy response of advanced renal cell carcinoma," Annals of Nuclear Medicine. 2010; 24(6): 441-6.

9. Linton RR, Barney JD, Moorman HD, Lerman J. Metastatic hypernephroma of the thyroid gland. Surg Gynecol Obstet. 1946; 83: 493-8.

\section{Comment on this article:}

\section{A 18 in $8+\mathbf{S} P$}

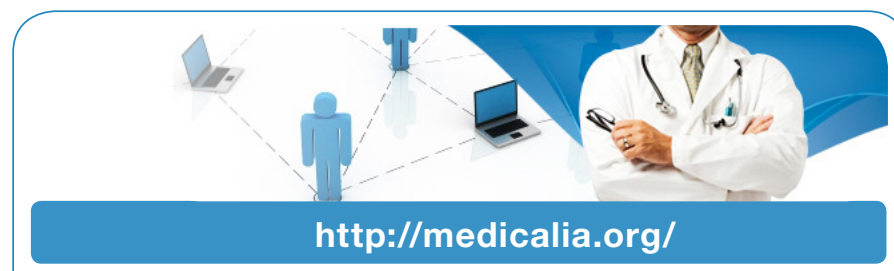

Where Doctors exchange clinical experiences, review their cases and share clinical knowledge. You can also access lots of medical publications for free. Join Now!

\section{Publish with iMedPub}

http://www.imed.pub

International Archives of Medicine is an open access journal publishing articles encompassing all aspects of medical science and clinical practice. IAM is considered a megajournal with independent sections on all areas of medicine. IAM is a really international journal with authors and board members from all around the world. The journal is widely indexed and classified Q1 in category Medicine. 